\title{
State Control, Marketization, And Firm Value: Evidence From China
}

Kun Su, Northwestern Polytechnical University, China Rui Wan, Nanjing University, China

\begin{abstract}
Using a firm-level panel data of Chinese listed firms, this paper examines the effects of state control on firm value and the different impacts that have under different degree of marketization deeply. The results show: compared with non-state controlled firms, state controlled firms are imposed by much policy burden and have more serious tunneling or expropriation behaviors. Therefore, firm values in state controlled firms are lower than in non-state controlled firms. For state controlled firms, the lower the government administrative ranks, the more serious the intervention or expropriation behaviors imposed by government, and thus the lower the firm value. Compared with low marketization regions, the negative effects of state control and low government administrative rank control on firm value is relatively smaller in regions with high degree of marketization.
\end{abstract}

Keywords: State Control; Government Intervention; Marketization; Firm Value

\section{INTRODUCTION}

Many firms are controlled by the state in emerging countries, like in China (La Porta et al., 1999; Sun and Tong, 2003). The importance of firm value has received considerable attention in academic research as well as in business practices. However, most of the researches often study the impacts of firm basic or governance characteristics on firm value just from the perspective of firm microscopic characteristics, ignoring the government behavior and the macro institutional environment. The effects of government on society and economy are much more significant in transition economy countries than in western developed countries since they typically have great social and economic resources (Chen, Lee and Li, 2008). The governments, especially local governments in China, often intervene in firms according to their private benefits, and exert much policy burdens on their controlled firms. They often affect the resource allocation by a "visible hand" (Chen, Lee and Li, 2008) in the pursuit of social and/or political gains rather than the economic objectives (Shleifer and Vishny, 1994; Taboada, 2011). Therefore, the firms whether controlled by state or controlled by different government administrative ranks will be different at firm values.

Despite the same legal origin, the degree of marketization varies widely among different regions in China due to different histories, natural environments, regional economic development choices, and social or cultural factors (Fan, Wang and Zhu, 2010). Regional marketization differences within China provide an unique setting to explore the impacts of state control on firm value under different marketization environments.

This paper combines the method of state control with marketization to study their effects on firm value. Specifically, this paper aimed to answer the following three questions: (1) Compared with non-state controlled firms, how about the effects of state control on firm value? (2) For state controlled firms, how about the effects of different administrative ranks of government control on firm value? (3) Do the above effects differ under various degrees of marketization regions? 


\section{THEORETICAL ANALYSIS AND HYPOTHESES}

The target of the establishment of China's security markets was for the reform of state controlled firms (Liu and $\mathrm{Lu}, 2007$ ). Consequently, state ownership accounted for approximately $70 \%$ of the total businesses in 2006 (Zou and Xiao, 2006). In China, the state controlled firms are always intervened by the government and take too much policy burdens imposed by government, such as the goal of employment, taxation, economic development, social stability or official promotion goals (Lin, Cai and Li, 1998; Yin, 2001; Li and Xia, 2008). The state controlled firms will change their operating behaviors while relating to the government's various political or social goals, which will lead to the deviation from the goal of maximizing firm value. Previous studies have found that the more intervention behaviors by the government, the more serious of the tunneling behavior and the lower of the firm values (Xu and Wang, 1999; Chen, Firth and Rui, 2006). Lo et al.(2010) find that the profit of state controlled firms is more likely to shift out and the tunneling effect will increase with the proportion of state ownership (Shan, 2013). In state controlled firms, even there exist government assisting behaviors, the ultimate goal are to serve for the grabbing behaviors (Li, Yu and Wang, 2005). Meanwhile, external regulatory or legal mechanisms are difficult to constrain the government tunneling behaviors, while relatively effective in restricting the entrenchment behaviors in non-state controlled firms. Compared with state controlled firms, the tunneling behaviors in non-state controlled firms are relatively lower (Zhu, 2006). Therefore, we have the following hypothesis.

Hypothesis 1: Compared with non-state controlled firms, the firm values are relatively lower in state controlled firms.

Under China's present political system, local governments are likely to be the agents of the central government and governments at different administrative ranks have different intervention extents in their controlled firms (Chen et al., 2008). Local governments are more likely to intervene in their controlled firms for short-term benefits. However, in central government controlled firms, the government intervention would be relatively lower due to the stringent regulation by many departments (Xu, 2004; Chen, Firth and Xu, 2009; Wang and Xiao, 2009). Generally speaking, the higher the government administrative ranks, the more attention paid to their reputation, which could restrain the government's grabbing behaviors and reduce the government intervention (Liu, Mao \& Yue, 2008). In addition, the fiscal decentralization reform since 1994 induces the fiscal revenue flowing into the central government overfull in China. The local governments have large duty to the social affairs, but with no corresponding fiscal revenue guarantee, especially for city or county governments (Yin, Chen and Pan, 2006). Therefore, the lower the government administrative rank, the larger the fiscal burden will be, and the more motivated to intervene in their controlled firms to alleviate the fiscal burden and achieve employment goals. Therefore, compared with central government, local governments have larger motivation to intervene in and tunnel their controlled firms. The lower the government administrative ranks, the stronger the intervention behaviors. Therefore, the following hypothesis is proposed:

Hypothesis 2: For state controlled firms, the lower the government administrative ranks, the lower the firm value of their controlled firms.

Institutional environment, especially degree of Marketization is an inherent external governance mechanism (Wei et al., 2011). China began its transition from a centrally planned system to a market economy since 1978, and the ensuring market-oriented reforms have resulted in decisive progress but also a widening regional disparity within the country (Wei et al., 2011). Marketization is the degree of allocating economic resources dominant by the market. Marketization plays a very important role in corporate governance system and can affect firm behaviors directly and indirectly through affecting various governance mechanisms. In regions with low degree of marketization, due to the imperfect legal environment and supervision mechanisms, the constraint effects on government intervention are relatively small. Thus, the governments, especially the low administrative rank government's grabbing behaviors are relatively more convenient in low degree of marketization regions. While in high degree of marketization regions, the legal environment is relatively perfect, tunneling behavior is effectively curbed as the cost of the government intervention or tunneling behavior greatly increase and expropriation is more likely to be exposed and punished, which will reduce the government intervention or expropriation behaviors and protect the interests of outside investors (Wei et al., 2011). The improvement of regional marketization can weaken the motivation and extent of local government intervention behaviors, and alleviate the policy burdens imposed by governments (Liu, Tian and Wang, 2011). Therefore, we propose the following hypotheses: 
Hypothesis 3: Compared with low degree of marketization regions, the negative impact of state control on firm value is relatively smaller in high degree of marketization regions.

Hypothesis 4: For state controlled firms, compared with low degree of marketization regions, the negative impact of low administrative rank of governments on firm value is relatively smaller in high degree of marketization regions.

\section{METHODS}

\subsection{Data Collection And Sample}

All the listed firms in Shanghai and Shenzhen Stock Exchange market are selected as our original samples over the period of 2007-2012. They were excluded from our sample if they are: (1) firms in financial industry; (2) ST (special treatment), PT (particular transfer) firms, since they are under the special financial situations. (3) firms with extreme variable values, like those with debt ratio either greater than 1 or smaller than 0 , and those with growth either greater than 2 or smaller than -0.5 ; (4) firms with uncompleted data. After the selection process, we obtain 7102 firm-year observations, with 1061 observations in 2007, 1159 observations in 2008, 1131 observations in 2009, 1152 observations in 2010, 1281 observations in 2011, and 1318 observations in 2012. The relevant data of state control are manually collected from the annual reports of listed firms, and the other data in this study come from CSMAR (China Stock Market and Accounting Research Database), which is the most widely used database on China's capital market (Su, Yang and Yang,2010; Su and Li, 2013).

\subsection{Measures}

\subsubsection{Dependent Measure}

Based on previous studies, we use Tobin's $Q$ to measure firm value, which is equivalent to the firm market value divided by total assets. In China, since there are tradable shares and non-tradable shares, we calculate the firm market value as the sum of total liability, market value of tradable shares and the book value of non-tradable shares.

\subsubsection{Independent Measures}

According to the analysis above, independent measures in this research include whether controlled by the state, government administrative ranks and the degree of marketization. By tracing the controlling chains of the listed firms, we find out the ultimate controller. According to the nature of the ultimate controller, we divide the sample into state controlled firms and non-state controlled firms. For state controlled firms, we divide them into three types based on the government administrative ranks according to the type of ultimate controllers: central government controlled firms, provincial government controlled firms, and city or county (or even more lower administrative rank) government controlled firms. If the state ultimate controller of a listed firm is a university, then the rank of the government controller of the firm is determined by the university's subordination. If firms are controlled by the central government, the variable of the government administrative rank is 1; when firms are controlled by the provincial government, the variable is 2 ; and when firms are controlled by the city or county government, the variable is 3 . We measure the degree of marketization of different regions that listed firms are registered in China as proposed by Fan et al. (2010) in the book "NERI Index of Marketization of China's Provinces", which have been used in previous studies (Wang, Wong and Xia, 2008; Li, Yue and Zhao, 2009). The larger the index value, the higher the degree of marketization.

\subsubsection{Other Measures}

Based on previous studies, we introduce the following control variables: (1) Firm size. Firm size is used to control its potential impact on firm value, which is measured by the natural logarithm of total asset of a firm at the end of the fiscal period. (2) Capital structure. We use asset-liability ratio to control the impact of debt on firm value. (3) Growth. We use the growth rate of sales to control the impact of growth on firm value. (4) Ownership concentration. Different ownership concentration represents different agency problems, and thus will affect the firm value. (5) Dual of chairman and CEO. When the two positions are the same person, the independence of the boards 
would be affected seriously, which will affect firm value further. (6) Industry. According to the "industry classification standard" issued by China Securities Regulatory Commission in 2001, the listed firms are divided into 13 broad industries. This paper further classifies the manufacturing industry (a predominant of the listed firms) into ten sub-categories in terms of the second-code classification criteria. After deleting the financial industry, the sample of this study consists of 21 industries. Taking the industry of agriculture, forestry, animal husbandry and fishery as the benchmark, 20 dummy variables are used to represent the industries. When listed firm belongs to a particular industry, the industry dummy variable takes the value of 1 , and 0 otherwise. Meanwhile, the sample period is from 2007 to 2012, so we take the year of 2007 as the benchmark, and select five dummy variables to represent the years.

The definitions of variables are summarized in Table 1:

Table 1: Definitions of Variables

\begin{tabular}{|c|c|c|c|}
\hline $\begin{array}{l}\text { Variable } \\
\text { Type }\end{array}$ & Name & Label & Definition and computation \\
\hline $\begin{array}{l}\text { Dependent } \\
\text { variable }\end{array}$ & Firm value & Tobin's $Q$ & $\begin{array}{l}\text { (Total liability+Market value of tradable share }+ \text { net asset per } \\
\text { share* } \\
\text { non-tradable share)/Total assets }\end{array}$ \\
\hline \multirow{3}{*}{$\begin{array}{l}\text { Independen } \\
\text { t variable }\end{array}$} & Whether controlled by state & STATE & $\begin{array}{l}1 \text { when the ultimate controller's property right is state, } 0 \\
\text { otherwise }\end{array}$ \\
\hline & $\begin{array}{l}\text { Government administrative } \\
\text { rank }\end{array}$ & GOVR & $\begin{array}{l}1 \text { when the firm controlled by central government, } 2 \text { when } \\
\text { controlled by provincial government, } 3 \text { when controlled by } \\
\text { city } \\
\text { or county government }\end{array}$ \\
\hline & Degree of Marketization & $M A R$ & $\begin{array}{l}\text { the marketization process index scores proposed by Fan et } \\
\text { al.(2010) }\end{array}$ \\
\hline \multirow{7}{*}{$\begin{array}{l}\text { Control } \\
\text { Variable }\end{array}$} & Firm size & $S I Z E$ & $\ln$ (Total assets) \\
\hline & Capital structure & $L E V$ & Total Liabilities/Total Assets \\
\hline & Growth & GROWTH & $\begin{array}{l}\text { ( sales of this period- sales of last period ) / sales of last } \\
\text { period }\end{array}$ \\
\hline & Ownership concentration & $B S E$ & The biggest shareholder's equity \\
\hline & Dual of the chairman and CEO & DUAL & 1 when the chairman and CEO is one person, 0 otherwise \\
\hline & Industry dummy & $I N D U S T R Y_{j}$ & 1 when the firm belongs to industry $\mathrm{j}, 0$ otherwise \\
\hline & Year dummy & $Y E A R_{k}$ & 1 when the year is $\mathrm{k}, 0$ otherwise \\
\hline
\end{tabular}

\subsection{Regression Models}

To test those hypotheses proposed above, we adopt the following regression models. Model (1) is used to test the $\mathrm{H} 1$ and $\mathrm{H} 2$. Variable $X_{i t}$ stands for the variables of whether controlled by state and government administrative ranks. This study predicts that the coefficient $\beta_{1}$ of $X_{\text {it }}$ is significantly smaller than 0 . Model (2) is used to test $\mathrm{H} 3$ and $\mathrm{H} 4$. We expect that $\beta_{2}$, the coefficient of the interaction term is significantly greater than 0 .

Tobin's $Q=\alpha_{0}+\beta_{1} X_{i t}+\beta_{2} S I Z E_{i t}+\beta_{3} L E V_{i t}+\beta_{4} G R O W T H_{i t}+\beta{ }_{5} B S E_{i t}$

$$
+\beta_{6} \text { DUAL }_{i t}+\sum_{\mathrm{j}=1}^{20} \beta_{(6+j)} \operatorname{INDUSTRY~}_{j i t}+\sum_{\mathrm{k}=1}^{5} \beta_{(26+k) Y E A R_{k i t}+\varepsilon_{\mathrm{it}}}
$$

Tobin's $Q=\alpha_{0}+\beta_{1} X_{i t}+\beta_{2} M A R * X_{i t}+\beta_{3} S_{Z Z E_{i t}}+\beta_{4} L E V_{i t}+\beta_{5} G R O W T H_{i t}+$

$$
\beta_{6} B S E_{i t}+\beta_{7} D U A L_{i t}+\sum_{\mathrm{j}=1}^{20} \beta_{(7+j)} \operatorname{INDUSTRY}_{j i t}+\sum_{\mathrm{k}=1}^{5} \beta_{(27+k)} Y E A R_{k i t}+\varepsilon_{\mathrm{it}}
$$

In the models above, $\alpha_{0}$ represents the intercept item, $\beta$ represents the regression coefficients, $\varepsilon$ denotes the error term, subscript i and trepresent firm and time respectively. 


\section{EMPIRICAL RESEARCH}

\subsection{Descriptive Statistics Analysis And The Mean Difference Test}

The descriptive statistics results of main variables for the sample and the t-test for the mean value difference are shown in table 2. As we can see from the table, the sample of the state controlled firms is 4825 , while the sample of non-state controlled firms is 2277 , the proportion of state controlled sample is $67.94 \%$. The mean value of Tobin's Q in state controlled firms is 1.5607, while the mean value in non-state controlled firms is 1.8219, and a significant difference from the t-test result of the mean difference, indicating that compared with non-state controlled firms, the firm value is relatively lower in state controlled firms, which is consistent with $\mathrm{H}_{1}$. Government administrative rank has an overall mean of 2.0711, which indicates that the number of listed firms controlled by the central government and those controlled by city or county government are approximately the same. The mean of marketization in state controlled firms is 8.2720 , while the mean in non-state controlled firms is 8.8414 , and a significant difference between them, indicating that non-state controlled firms account for a larger proportion in more developed regions. From the control variables, we can see that except for growth, the mean of all the other variables are significantly different between the two kinds of firms.

Table 2: Descriptive Statistics and Mean Value T-test

\begin{tabular}{|c|c|c|c|c|c|c|c|c|}
\hline Variable & Property Right & Obs. & Min. & Max. & Mean & SD. & Var. & T-test \\
\hline \multirow{2}{*}{ Tobin's $Q$} & State & 4825 & 0.7341 & 16.3983 & 1.5607 & 0.8328 & 0.6936 & $-0.2613 * * *$ \\
\hline & Non-state & 2277 & 0.7720 & 14.4621 & 1.8219 & 1.1558 & 1.3358 & $(-9.6674)$ \\
\hline GOVR & State & 4825 & 1.0000 & 3.0000 & 2.0711 & 0.8194 & 0.6714 & \\
\hline \multirow{2}{*}{$M A R$} & State & 4825 & 1.5500 & 11.7100 & 8.2720 & 2.0278 & 4.1122 & $-0.5695^{* * *}$ \\
\hline & Non-state & 2277 & 1.5500 & 11.7100 & 8.8414 & 2.0887 & 4.3628 & $(-10.8232)$ \\
\hline \multirow{2}{*}{ SIZE } & State & 4825 & 18.2659 & 28.0031 & 21.7390 & 1.1445 & 1.3099 & $0.5893 * * *$ \\
\hline & Non-state & 2277 & 18.3224 & 24.9478 & 21.1497 & 0.9071 & 0.8228 & $(23.4250)$ \\
\hline \multirow{2}{*}{$L E V$} & State & 4825 & 0.0081 & 0.9824 & 0.5031 & 0.1794 & 0.0322 & $0.0242 * * *$ \\
\hline & Non-state & 2277 & 0.0178 & 0.9938 & 0.4789 & 0.1834 & 0.0336 & $(5.2781)$ \\
\hline \multirow{2}{*}{ GROWTH } & State & 4825 & -0.4927 & 1.9877 & 0.1809 & 0.2976 & 0.0885 & 0.0081 \\
\hline & Non-state & 2277 & -0.4977 & 1.9292 & 0.1728 & 0.3387 & 0.1147 & $(0.9786)$ \\
\hline \multirow{2}{*}{$B S E$} & State & 4825 & 6.4700 & 86.4200 & 41.1279 & 15.9036 & 252.9244 & $8.5125 * * *$ \\
\hline & Non-state & 2277 & 4.4900 & 85.2300 & 32.6154 & 13.5380 & 183.2764 & (23.3496) \\
\hline \multirow{2}{*}{$D U A L$} & State & 4825 & 0.0000 & 1.0000 & 0.0926 & 0.2900 & 0.0841 & $-0.1037 * * *$ \\
\hline & Non-state & 2277 & 0.0000 & 1.0000 & 0.1963 & 0.3973 & 0.1578 & $(-11.1307)$ \\
\hline
\end{tabular}

Notes: The values in ( ) are t-statistic. The values upon ( ) are the difference of the two kinds of samples' mean value and the significance of the t-test. *, **, *** represent significant at the $10 \%, 5 \%$ and $1 \%$ level, respectively.

\subsection{Correlation Analysis}

The Pearson correlation coefficients of all variables are shown in table 3. The variable of whether controlled by the state is negatively related to Tobin's Q, and the coefficient is significant at the $1 \%$ level, implying that listed firms controlled by the state have relatively lower firm value than firms controlled by non-state entities, which is consistent with $\mathrm{H}_{1}$. The variable that represents government administrative rank is negatively related to Tobin's Q, and the coefficient is significant at the $1 \%$ level. The lower the government administrative rank, the lower the firm value of their controlled firms, which is consistent with $\mathrm{H}_{2}$. The variable of marketization is significantly positively related to firm value, indicating that the firm value is relatively higher in regions with high degree of marketization. Relationships between other control variables and Tobin's $Q$ are as expected. 
Table 3: Pearson Correlation Analysis

\begin{tabular}{|c|c|c|c|c|c|c|c|c|c|}
\hline & Tobin's $Q$ & STATE & GOVR & $M A R$ & SIZE & $L E V$ & GROWTH & $B S E$ & $D U A L$ \\
\hline Tobin's $Q$ & 1.0000 & & & & & & & & \\
\hline STATE & $-0.1275 * * *$ & 1.0000 & & & & & & & \\
\hline GOVR & $-0.0708 * * *$ & & 1.0000 & & & & & & \\
\hline$M A R$ & $0.1125^{* * *}$ & $-0.1287 * * *$ & $-0.0359 * *$ & 1.0000 & & & & & \\
\hline SIZE & $-0.1896 * * *$ & $0.2481 * * *$ & $-0.1502 * * *$ & $0.1029 * * *$ & 1.0000 & & & & \\
\hline$L E V$ & $-0.2225 * * *$ & $0.0625^{* * *}$ & $0.0547 * * *$ & $-0.0312 * * *$ & $0.3018 * * *$ & 1.0000 & & & \\
\hline GROWTH & 0.0028 & 0.0122 & $-0.0392 * * *$ & $-0.0604 * * *$ & $0.0996 * * *$ & $0.0619 * * *$ & 1.0000 & & \\
\hline$B S E$ & $-0.1549 * * *$ & $0.2531 * * *$ & $-0.0962 * * *$ & $-0.0357 * * *$ & $0.2460 * * *$ & $-0.0321 * * *$ & $0.0917 * * *$ & 1.0000 & \\
\hline$D U A L$ & $0.0679 * * *$ & $-0.1459 * * *$ & $0.1128 * * *$ & $0.0642 * * *$ & $-0.0973 * * *$ & $-0.0563 * * *$ & $-0.0253 * *$ & $-0.0681 * * *$ & 1.0000 \\
\hline
\end{tabular}

Note; $* * *, * * *$ represent significant at the $10 \%, 5 \%$, and $1 \%$ level respectively.

\subsection{Multiple Regression Analysis}

The results of multiple regression analysis are shown in table 4. The F value of each model is significant at the $1 \%$ level, which shows that the overall fit degree of each model is relatively well. The variance inflation factor (VIF) testing the severity of multi-collinearity is far less than 10 , and the value of the tolerance is far larger than 0.1 (Due to space limitation, the VIF values and tolerance of each variables are not listed in the table), which also suggest that the problem of multi-collinearity does not exist in these models. The D.W values of each regression equation are all around 2, which implying that the autocorrelation problem is not serious here.

It can be seen from columns (1) in Table 4 that the variable whether controlled by the state is significantly negatively related to firm value, suggesting that state controlled firms are imposed much more policy burden by governments and have more serious tunneling or expropriation behaviors. Therefore, compared with non-state controlled firms, the firm values are relatively lower in state controlled firms, which support $\mathrm{H}_{1}$. In column (2) of table 4 , the estimated coefficient on the variable of whether controlled by the state is still negative, but the interaction of the degree of marketization with the variable of whether controlled by the state is significantly positively related to firm value. Thus the positive coefficient on the interaction term implies that in regions with a higher degree of marketization, state control plays a relatively weaker role in firm value than in regions with a lower degree of marketization. The negative impact of state control on firm value is relatively smaller in high degree of marketization regions than in low degree of marketization regions. So, $\mathrm{H}_{3}$ is supported.

Column (3) in Table 4 indicates that the variable that represents government administrative rank is significantly negatively related to firm value. Since larger values of the variable represent a lower administrative rank of government, the result implies that the lower the government administrative rank, the stronger the motivation for the government to intervene and tunnel their controlled firms, which reduced firm value. Therefore, H2 is supported. In column (4), the estimated coefficient on government administrative rank is still negative, but the interaction term of the degree of marketization with the government administrative rank is significantly positively related to firm value. Thus the positive coefficient on the interaction term implies that in regions with a higher degree of marketization, government administrative rank plays a relatively weaker role in firm value than in regions with a lower degree of marketization, which support $\mathrm{H}_{4}$.

Based on the analysis of control variables in Tables 4, we generate the following statements: Firm size is significantly negatively related to firm value. It means that the larger the firm size, the lower the firm value. Capital structure also displays a significantly negative relationship with firm value, which shows that the higher the debt level, the lower the firm value. Growth is significantly positively related to firm value, suggesting that high growth can lead to high firm value. Ownership concentration and firm value is significantly negatively related, indicating that high concentration equity structure reduced the firm value in China. In the total sample, dual of the chairman and CEO doesn't have significant impact on firm value. While in state controlled sample, dual of the chairman and CEO has significantly positive impact on firm value. There are large differences in firm value among different industries or years. 
Table 4: Regression Results

\begin{tabular}{|c|c|c|c|c|c|}
\hline \multirow[b]{2}{*}{ Variable } & \multirow[b]{2}{*}{ Expected sign } & \multicolumn{4}{|c|}{ Tobin's $Q$} \\
\hline & & (1) & (2) & (3) & (4) \\
\hline Constant & $?$ & $\begin{array}{c}5.0895 * * * \\
(26.0171)\end{array}$ & $\begin{array}{c}5.1684 * * * \\
(25.8932)\end{array}$ & $\begin{array}{r}4.8400 * * * \\
(23.1989)\end{array}$ & $\begin{array}{c}4.9287 * * * \\
(23.1129)\end{array}$ \\
\hline STATE & - & $\begin{array}{c}-0.0401 * * \\
(-1.9603)\end{array}$ & $\begin{array}{r}-0.1355 * * * \\
(-2.5891)\end{array}$ & & \\
\hline MARSTATE & + & & $\begin{array}{c}0.0115 * * \\
\quad(1.9800)\end{array}$ & & \\
\hline GOVR & - & & & $\begin{array}{r}-0.0865 * * * \\
(-7.2328)\end{array}$ & $\begin{array}{r}-0.1255 * * * \\
(-5.4860)\end{array}$ \\
\hline MARGOVR & + & & & & $\begin{array}{l}0.0046^{* * *} \\
(1.9970)\end{array}$ \\
\hline SIZE & - & $\begin{array}{r}-0.1574 * * * \\
(-16.7724)\end{array}$ & $\begin{array}{r}-0.1602 * * * \\
(-16.8841)\end{array}$ & $\begin{array}{r}-0.1434 * * * \\
(-14.9522)\end{array}$ & $\begin{array}{r}-0.1461 * * * \\
(-15.0891)\end{array}$ \\
\hline$L E V$ & - & $\begin{array}{r}-0.7800 * * * \\
(-14.5144)\end{array}$ & $\begin{array}{r}-0.7734 * * * \\
(-14.3682)\end{array}$ & $\begin{array}{r}-0.6897 * * * \\
(-12.1426)\end{array}$ & $\begin{array}{r}-0.6810 * * * \\
(-11.9571)\end{array}$ \\
\hline GROWTH & + & $\begin{array}{r}0.2039 * * * \\
(6.9899)\end{array}$ & $\begin{array}{r}0.2072 * * * \\
(7.0908)\end{array}$ & $\begin{array}{r}0.1871 * * * \\
(5.8278)\end{array}$ & $\begin{array}{r}0.1907 * * * \\
(5.9322)\end{array}$ \\
\hline$B S E$ & - & $\begin{array}{r}-0.0037 * * * \\
(-6.0456)\end{array}$ & $\begin{array}{r}-0.0038 * * * \\
(-6.1002)\end{array}$ & $\begin{array}{r}-0.0022 * * * \\
(-3.5151)\end{array}$ & $\begin{array}{r}-0.0023 * * * \\
(-3.6018)\end{array}$ \\
\hline$D U A L$ & - & $\begin{array}{l}0.0400 \\
(1.4848)\end{array}$ & $\begin{array}{l}0.0408 \\
(1.5120)\end{array}$ & $\begin{array}{r}0.0942 * * * \\
(2.9374)\end{array}$ & $\begin{array}{r}0.0949 * * * \\
(2.9601)\end{array}$ \\
\hline INDUSTRY & & Controlled & Controlled & Controlled & Controlled \\
\hline$Y E A R$ & & Controlled & Controlled & Controlled & Controlled \\
\hline Adjust $R^{2}$ & & 0.4045 & 0.4047 & 0.4184 & 0.4187 \\
\hline F value & & $156.5651 * * *$ & $151.8576 * * *$ & $116.6567 * * *$ & $113.0926 * * *$ \\
\hline D.W value & & 1.9344 & 1.9357 & 1.9326 & 1.9349 \\
\hline Obs & & 7102 & 7102 & 4825 & 4825 \\
\hline
\end{tabular}

Note: the number in the ( ) represents t value; $*, * *, * *$ represent significant at the $10 \%, 5 \%$ and $1 \%$ level, respectively.

\section{CONCLUSION}

This study investigates the impacts of state control on firm value and the differences of that impact among regions with different degree of marketization deeply. From a sample of 7102 listed firms from 2007 to 2012 in China, we found that the state commonly intervenes in listed firms and reduced firm value, and the improvement of marketization helps to mitigate the impact of state control on firm value. Specifically, our results show that the state often imposes much policy burden on their controlled firms and tunnel them for private benefits. Therefore, compared with non-state controlled firms, the firm values are relatively lower in state controlled firms. For state controlled firms, the lower the government administrative rank, the stronger the motivation for them to intervene in and tunnel their controlled firms, and therefore the lower the firm values in their controlled firms. However, the cost to the state of intervention is higher in regions with high degree of marketization than in regions with less-developed regions. With the improvement of marketization, the negative effects of state control on firm value declines gradually. Simar to the above, for state controlled firms, the negative impact of low rank governments on firm value is relatively smaller in high degree of marketization regions than in low degree of marketization regions. The results show that state control especially low administrative ranks of governments have significantly negative impacts on firm value, while the improvement of marketization can mitigate the negative effects.

\section{ACKNOWLEDGEMENTS}

This research was partially supported by the National Natural Science Foundation of China (No. 71402141), the Humanity and Social Science Youth Foundation of the Ministry of Education of China (No. 14YJC790103), the Natural Science Foundation of Shaanxi Province (No. 2014JQ9370), the Social Science Foundation of Shaanxi Province (No. 13D211) and the Fundamental Research Funds for the Central Universities in Northwestern Polytechnical University (No. 3102014RW0004). 


\section{AUTHOR INFORMATION}

Dr. Kun Su is an assistant professor of accounting in the School of Management at Northwestern Polytechnical University. His main research interests include corporate governance, financial disclosure, and corporate finance. Email:suk711@126.com

Dr. Rui Wan is an assistant professor of economics in the School of Economics at Nanjing University. Her main research interests include corporate governance, environmental economics and welfare economics. E-mail: ruwan@ucalgary.ca (Corresponding author)

\section{REFERENCES}

1. Chen G, Firth M, Rui O. (2006). Have China's enterprise reforms led to improved efficiency and profitability?. Emerging Markets Review, (7): 82-109.

2. Chen G., Firth M, Xu L.(2009). Does the type of ownership control matter? evidence from China's listed companies, Journal of Banking \& Finance, 33 (1): 171-181.

3. Chen X., Lee CJ and Li J. (2008). Government assisted earnings management in China. Journal of Accounting and Public Policy, 27(3): 262-274.

4. Fan G., Wang X and Zhu H. (2010). NERI Index of Marketization of China's Provinces_- The Report on the Relative Process of Marketization of Each Region in China, Economics Science Press

5. La Port R, Lopez-De-Silanes F, Shleifer A. (1999). Corporate ownership around the world. Journal of Finance, (54):471-517.

6. Li K., Yue H. and Zhao L. (2009). Ownership, institutions, and capital structure: evidence from China, Journal of Comparative Economics, 37 (3):471-490.

7. Li S, Xia J. (2008). The roles and performance of state firms and non-state firms in China's economic transition. World Development, 36(71): 39-54.

8. Li Z, Yu Q, Wang X. (2005). Tunneling, propping and M\&A: evidence from Chinese listed companies. Economic Journal, (1): 95-105.

9. Lin J, Cai F, Li Z. (1998). Competition, policy burdens and state-owned enterprise reform. American Economic Review, 88(2): 422-427.

10. Liu Q, Tian G and Wang X. (2011). The effect of ownership structure on leverage decision: new evidence from Chinese listed firms, Journal of the Asia Pacific Economy, 16(2): 254-276.

11. Liu Q, Lu ZJ. (2007). Corporate governance and earnings management in the Chinese listed companies: a tunneling perspective. Journal of Corporate Finance, 13(5):881-906.

12. Liu Z, Mao S, Yue G. (2008). Government control, ultimate controlling shareholder and debt maturity of listed companies. Contemporary Finance \& Economics, (1): 102-108.

13. Lo AWY., Wong RMK and Firth M. (2010). Tax, financial reporting, and tunneling incentives for income shifting: an empirical analysis of the transfer pricing behavior of Chinese listed companies, Journal of the American Taxation Association, (32):1-26.

14. Shan YG. (2013). Can internal governance mechanisms prevent asset appropriation? Examination of type I tunneling in China, Corporate Governance: An International Review, 21(3):225-241.

15. Shleifer A, Vishny R. (1994). Politicians and firms. Quarterly Journal of Economics, 109(4): 995-1025.

16. Su K, Li P. (2013). The effects of ultimate controlling shareholders on debt maturity structure, Journal of Applied Business Research, 29(2): 553-560.

17. Su K, Yang S, Yang B. (2010). Ultimate ownership and firm performance: evidence from Chinese privated listed firms. International Journal of Management Science and Engineering Management, 5(3):182-191.

18. Sun Q, Tong W. (2003). China share issue privatization: the extent of its success. Journal of Financial Economics, 70(2), 183-222.

19. Taboada A G.. (2011). The impact of changes in bank ownership structure on the allocation of capital: International evidence. Journal of Banking and Finance, 35 (10): 2528-2543.

20. Wang K and Xiao X. (2009). Ultimate government control structures and firm value: evidence from Chinese listed companies, China Journal of Accounting Research, 2 (1): 101-122.

21. Wang Q., Wong TJ and Xia L. (2008). State ownership, the institutional environment, and auditor choice: evidence from China, Journal of Accounting and Economics, 146 (1):112-134. 
22. Wei Z., Wu S., Li C and Chen W. (2011). Family control, institutional environment and cash dividend policy: evidence from China, China Journal of Accounting Research, (4):29-46.

23. Xu L. (2004). Types of large shareholders, corporate governance, and firm performance. Hongkong. Hong Kong Polytechnic University.

24. Xu X, Wang Y. (1999). Ownership structure and corporate governance in Chinese stock companies. China Economic Review, (10): 75-98.

25. Yin X. (2001). A dynamic analysis of overstaff in China's state-owned enterprises. Journal of Development Economics, 66(1): 87-99.

26. Yin XG, Chen G and Pan Y. (2006). Tax sharing reform, governmental intervention and the efficiency of financial development, Journal of Finance and Economics, 32 (10): 92-101.

27. Zhu S. (2006). The characteristics of ultimate shareholders, government control and the value of firms. China Management Studies, 1(1):98-119.

28. Zou H, Xiao JZ. (2006). The financing behavior of listed Chinese firms. The British Accounting Review, 38(3):239-258. 


\section{NOTES}

